\section{Comparative Vertical Migration of Three Different Strains of Heterorhabditis bacteriophora and a Single Strain of Heterorhabditis megidis in Sand at $25^{\circ} \mathrm{C}$}

\author{
Attila Sándor Csontos ${ }^{1}$ - Parwinder S. Grewal ${ }^{2}$ - \\ Michael G. Klein ${ }^{2}$ \\ ${ }^{1}$ University of Debrecen, Centre for Agricultural Sciences, \\ Faculty of Agricultural Sciences, \\ Department of Plant Protection, Debrecen \\ ${ }^{2}$ Ohio Agricultural Research and Development Center, \\ Wooster, Ohio, USA
}

\section{SUMMARY}

Four heterorhabditid isolates (three different strains of Heterorhabditis bacteriophora and Heterorhabditis megidis) were tested for downward migration in $9.5 \mathrm{~cm}$ vertical sand columns at $25^{\circ} \mathrm{C}$ with and without a larva of the wax moth, Galleria mellonella, at the bottom. The number of infective juveniles (IJs) in the upper section decreased since the IJs gradually migrated down toward the Galleria larvae into the lower section of the shell vials. Only the isolate $\mathrm{OH} 25$ behaved differently, because the number of IJs decreased this isolate in the lower section. This isolate was the quickest, since after 12 hrs, most IJs could be found in the lower section of the vials from this isolate. The number of IJs was so small in the lower section that 12 hrs after injection, only the isolates MHG 3 and $\mathrm{OH} 25$ could kill the Galleria larvae.

Besides the fact that mortality occurred among the Galleria larvae with the above isolates, neither IJs nor adults could be detected in either living or dead Galleria larvae 12 hrs after IJ injection. It is noteworthy that the behavior of the isolate Megidis was different from the other isolates: the number of IJs was so negligible in the lower section of the vials that even after 36 hrs none of the Galleria died and, consequently, neither adults nor IJs could be detected after dissecting the Galleria larvae. Each isolate could reach the lower section of the vials, yet only the isolate Megidis could not infect and kill the host. After dissecting the larvae, most IJs and adults could be found in the isolate MHG 3 (95 IJs and adults altogether) 36 hrs after injection.

\section{INTRODUCTION}

Laboratory studies show that nematodes respond positively to many chemical stimuli produced by insects (Gaugler et al., 1980). Many factors influence nematode movement in soil. Probably the most important factors are soil texture (Georgis and Poinar, 1983), temperature (Steiner, 1996), behavior of the nematode species (Grewal et al., 1994), genetic differences of species and strains (Glazer et al., 1991), presence or absence of a host (Molyneux, 1983) and moisture (Molyneux and Bedding, 1984). Although there are many stimuli that play an important role in the host-finding tactic of the nematodes, it seems that neither of the stimuli is predominant, but rather more stimuli influence and integrate together this process (Gaugler et al., 1980).

The host-finding tactic of entomopathogenic nematodes can be "cruiser" (actively searching foragers), "ambusher" (sit-and-wait foragers) or “intermediate” (Kaya and Gaugler, 1993). Direct response to host chemical cues (Lewis et al., 1992), active dispersal and an inability to nictate are the characteristics of cruisers, such as Heterorhabditis bacteriophora (Poinar) and Heterorhabditis megidis (Poinar), whereas less dispersing activity and active nictating are characteristic features among ambushers (Campbell and Gaugler, 1993).

This paper reports on laboratory tests of the vertical dispersal of four heterorhabditid isolates. The objective of this experiment was to examine the comparative movement of three different strains of $H$. bacteriophora and $H$. megidis in sand. The information gained from this experiment may enable us to use the above strains and species more effectively in the field as a biological control agent.

\section{MATERIALS AND METHODS}

Stock cultures of infective juveniles (IJs) of $H$. bacteriophora (strains: MHG 3, KMD 19, OH 25) and $H$. megidis were maintained by infecting fourth instar larvae of the greater wax moth (Galleria mellonella). The IJs were collected daily from cadavers placed on White traps (White, 1924). The emerged IJs were stored in Ehrlenmeyer flasks and maintained at $9^{\circ} \mathrm{C}$ in tap water, at a concentration of ca. 2000 nematodes $/ \mathrm{ml}$. Nematode suspensions were cleaned by decanting and adding fresh tap water. All IJs were used between five and ten days after their emergence from host cadavers.

Sand was used in this experiment. The sand was sterilized in an autoclave at $90^{\circ} \mathrm{C}$ for $99 \mathrm{~min}$. After cooling, the moisture content was measured and adjusted to seven\%.

Shell vials (diameter $2.5 \mathrm{~cm}$, height $9.5 \mathrm{~cm}$ ) were filled with sand and used as a container. A plastic sieve was used to make an upper (upper seven $\mathrm{cm}$ ) and a lower section (the bottom $2.5 \mathrm{~cm}$ ) in the vials. This assay was conducted twice (five replicates each) and the data were merged, making a total of ten replicates at each time period (12, 24 and 36 hrs). A total of ten controls were also conducted at each time period. A total of 120 vials per trial were used with each nematode isolates. The vials were separated into three groups. Each group contained ten replicates and ten control vials. The first group of vials was placed in a $25^{\circ} \mathrm{C}$ incubator for $12 \mathrm{~h}$, the second group for 24 $\mathrm{h}$ and the third group for $36 \mathrm{~h}$. 
Immediately after preparation, vials with and without a last instar larva of $G$. mellonella at the bottom, approximately 500 IJs in $0.5 \mathrm{ml}$ water were injected into the upper layer and covered with a plastic lid to retard the sand from drying. The IJs were tested for downward migration: nematode response to the host insect was monitored by recording the number of IJs found in the upper (seven $\mathrm{cm})$ and in the lower section $(2.5 \mathrm{~cm})$ of the vials.

After 12, 24 and $36 \mathrm{~h}$, the upper and the lower sand column in the vials were separated and put onto Baerman funnels for $72 \mathrm{~h}$. After $72 \mathrm{~h}$, the samples were collected separately into screw-capped glass tubes (O.D. x L $=1.5 \mathrm{~cm} \times 15 \mathrm{~cm}$ ) and stored in a refrigerator at $9^{\circ} \mathrm{C}$ till counting. The recovered insect larvae were washed and incubated for 72 hours in Petri dishes (five $\mathrm{cm}$ diameter) taped with parafilm for reduced dehydration at $25^{\circ} \mathrm{C}$.

After 72 hours, all G. mellonella larvae were dissected and both IJs and adults were counted separately. Petri dishes (nine $\mathrm{cm}$ diameter) were used as containers for nematode solutions during nematode counting. The experiment was repeated two times giving a total of 960 samples. All data were subject to analysis of variance (ANOVA) at $\mathrm{P}<0.05$ using Statistica statistical package. The significant differences among the different strains were calculated. The experiment was carried out in Wooster, OH (USA) at the OARDC Lab. of the Ohio State University.

\section{RESULTS}

The majority of IJs remained in the upper section of the shell vials where they were injected previously. The number of IJs recovered in the lower section in most of the isolates increased as time went by.

\section{MHG 3}

At $12 \mathrm{hrs}$, an average of $271 \mathrm{IJs}$ were recovered out of 500 (the extraction efficiency was 54\%) whereas at 24 hrs, an average of 235 IJs (47\%) and, at 36 hrs, an average of 224 IJs (45\%) were recovered out of 500 . The number of IJs recovered in the lower section increased as time went by. At 12 hrs, an average of $94.1 \%$ of the IJs were recovered in the upper section and only 5.9\% in the lower section, whereas at 24 hrs $91.5 \%$ were recovered in the upper and $8.5 \%$ in the lower and, at $36 \mathrm{hrs}, 91.9 \%$ in the upper and only $8.5 \%$ in the lower section on the average (Table 1).

Table 1

Infective juveniles of Heterorhabditis bacteriophora (MHG 3) detected in the lower and upper sections of the vials and in the Galleria larvae 12, 24 and 36 after injection

\begin{tabular}{|c|c|c|c|c|c|c|c|c|c|c|c|c|c|c|c|c|c|c|}
\hline \multirow{4}{*}{\begin{tabular}{|}
$\begin{array}{c}\text { Serial } \\
\text { number } \\
\text { of } \\
\text { replicates }\end{array}$ \\
.
\end{tabular}} & \multicolumn{6}{|c|}{12 hrs } & \multicolumn{6}{|c|}{24 hrs } & \multicolumn{6}{|c|}{36 hrs } \\
\hline & \multicolumn{4}{|c|}{ Number of IJs in } & \multirow{3}{*}{$\begin{array}{c}\text { Total } \\
\text { nema } \\
\text { tode }\end{array}$} & \multirow{3}{*}{$\%$} & \multicolumn{4}{|c|}{ Number of IJs in } & \multirow{3}{*}{$\mid \begin{array}{c}\text { Total } \\
\text { nema } \\
\text { tode }\end{array}$} & \multirow{3}{*}{$\%$} & \multicolumn{4}{|c|}{ Number of IJs in } & \multirow{3}{*}{$\mid \begin{array}{c}\text { Total } \\
\text { nema } \\
\text { tode }\end{array}$} & \multirow{3}{*}{$\%$} \\
\hline & \multirow{2}{*}{$\begin{array}{c}\text { upper } \\
\text { section }\end{array}$} & \multirow{2}{*}{$\begin{array}{c}\text { lower } \\
\text { section }\end{array}$} & \multicolumn{2}{|c|}{ Galleria } & & & \multirow{2}{*}{$\begin{array}{c}\text { upper } \\
\text { section }\end{array}$} & \multirow{2}{*}{$\begin{array}{c}\text { lower } \\
\text { section }\end{array}$} & \multicolumn{2}{|c|}{ Galleria } & & & \multirow{2}{*}{$\begin{array}{c}\text { upper } \\
\text { section }\end{array}$} & \multirow{2}{*}{$\begin{array}{c}\text { lower } \\
\text { section } \\
\end{array}$} & \multicolumn{2}{|c|}{ Galleria } & & \\
\hline & & & Adult & IJs & & & & & Adult & IJs & & & & & Adult & IJs & & \\
\hline 1. & 313 & 17 & 0 & 0 & 330 & 66 & 196 & 8 & 1 & 6 & 204 & 41 & 203 & 23 & 29 & 88 & 226 & 45 \\
\hline 2. & 204 & 7 & 0 & 0 & 211 & 42 & 121 & 22 & 5 & 18 & 143 & 29 & 181 & 15 & 53 & 76 & 196 & 39 \\
\hline 3. & 206 & 19 & 0 & 0 & 225 & 45 & 302 & 17 & 10 & 15 & 319 & 64 & 178 & 21 & 36 & 81 & 199 & 40 \\
\hline 4. & 267 & 11 & 0 & 0 & 278 & 56 & 226 & 14 & 2 & 9 & 240 & 48 & 166 & 19 & 44 & 93 & 185 & 37 \\
\hline 5. & 248 & 16 & 0 & 0 & 264 & 53 & 143 & 24 & 8 & 16 & 167 & 33 & 191 & 16 & 49 & 84 & 207 & 41 \\
\hline 6. & 192 & 26 & 0 & 0 & 218 & 44 & 297 & 26 & 2 & 9 & 323 & 65 & 268 & 14 & 21 & 23 & 282 & 56 \\
\hline 7. & 295 & 16 & 0 & 0 & 311 & 62 & 236 & 31 & 4 & 14 & 267 & 53 & 192 & 27 & 16 & 21 & 219 & 44 \\
\hline 8. & 296 & 8 & 0 & 0 & 304 & 61 & 276 & 12 & 5 & 7 & 288 & 58 & 272 & 23 & 32 & 46 & 295 & 59 \\
\hline 9. & 226 & 19 & 0 & 0 & 245 & 49 & 184 & 24 & 3 & 19 & 208 & 42 & 196 & 12 & 38 & 51 & 208 & 42 \\
\hline 10. & 301 & 23 & 0 & 0 & 324 & 65 & 169 & 19 & 7 & 21 & 188 & 38 & 209 & 16 & 26 & 49 & 225 & 45 \\
\hline Mean & 255 & 16 & 0 & 0 & 271 & 54 & 215 & 20 & 5 & 13 & 235 & 47 & 206 & 19 & 34 & 61 & 224 & 45 \\
\hline \multicolumn{19}{|l|}{ Control } \\
\hline 1. & 226 & 76 & & & 302 & 60 & 232 & 23 & & & 255 & 51 & 224 & 21 & & & 245 & 49 \\
\hline 2. & 189 & 59 & & & 248 & 50 & 194 & 10 & & & 204 & 41 & 285 & 17 & & & 302 & 60 \\
\hline 3. & 177 & 43 & & & 220 & 44 & 238 & 13 & & & 251 & 50 & 164 & 15 & & & 179 & 36 \\
\hline 4. & 151 & 64 & & & 215 & 43 & 212 & 17 & & & 229 & 46 & 234 & 19 & & & 253 & 51 \\
\hline 5. & 202 & 71 & & & 273 & 55 & 246 & 19 & & & 265 & 53 & 259 & 18 & & & 277 & 55 \\
\hline 6. & 212 & 34 & & & 246 & 49 & 298 & 21 & & & 319 & 64 & 254 & 26 & & & 280 & 56 \\
\hline 7. & 191 & 34 & & & 225 & 45 & 206 & 16 & & & 222 & 44 & 214 & 31 & & & 245 & 49 \\
\hline 8. & 196 & 28 & & & 224 & 45 & 241 & 18 & & & 259 & 52 & 242 & 22 & & & 264 & 53 \\
\hline 9. & 202 & 46 & & & 248 & 50 & 162 & 9 & & & 171 & 34 & 266 & 16 & & & 282 & 56 \\
\hline 10. & 187 & 37 & & & 224 & 45 & 271 & 11 & & & 282 & 56 & 234 & 24 & & & 258 & 52 \\
\hline Mean & 193 & 49 & & & 243 & 49 & 230 & 16 & & & 246 & 49 & 238 & 21 & & & 259 & 52 \\
\hline
\end{tabular}


KMD 19

At 12 hrs, an average of 230 IJs were recovered out of 500 (the extraction efficiency was 46\%), whereas at 24 hrs, an average of 282 IJs (56\%) and, at 36 hrs, an average of 296 IJs (59\%) were recovered out of 500. The number of IJs recovered in the lower section increased as time went by. At 12 hrs, an average of $97.8 \%$ of the IJs were recovered in the upper section and only $2.6 \%$ in the lower section whereas at $24 \mathrm{hrs}, 90.8 \%$ were recovered in the upper and $9.2 \%$ in the lower and, at 36 hrs, $91.2 \%$ in the upper and only $8.8 \%$ in the lower section on the average (Table 2).

Table 2

Infective juveniles of Heterorhabditis bacteriophora (KMD 19) detected in the lower and upper sections of the vials and in the Galleria larvae 12, 24 and 36 after injection

\begin{tabular}{|c|c|c|c|c|c|c|c|c|c|c|c|c|c|c|c|c|c|c|}
\hline \multirow{4}{*}{$\begin{array}{c}\text { Serial } \\
\text { number } \\
\text { of } \\
\text { replicates }\end{array}$} & \multicolumn{6}{|c|}{$12 \mathrm{hrs}$} & \multicolumn{6}{|c|}{$24 \mathrm{hrs}$} & \multicolumn{6}{|c|}{$36 \mathrm{hrs}$} \\
\hline & \multicolumn{4}{|c|}{ Number of IJs in } & \multirow{3}{*}{$\begin{array}{c}\text { Total } \\
\text { nema } \\
\text { tode } \\
\end{array}$} & \multirow{3}{*}{$\%$} & \multicolumn{4}{|c|}{ Number of IJs in } & \multirow{3}{*}{$\begin{array}{c}\text { Total } \\
\text { nema } \\
\text { tode }\end{array}$} & \multirow{3}{*}{$\%$} & \multicolumn{4}{|c|}{ Number of IJs in } & \multirow{3}{*}{\begin{tabular}{|c|} 
Total \\
nema \\
tode
\end{tabular}} & \multirow{3}{*}{$\%$} \\
\hline & \multirow{2}{*}{$\begin{array}{c}\text { upper } \\
\text { section }\end{array}$} & \multirow{2}{*}{$\begin{array}{c}\text { lower } \\
\text { section }\end{array}$} & \multicolumn{2}{|c|}{ Galleria } & & & \multirow{2}{*}{$\begin{array}{c}\text { upper } \\
\text { section }\end{array}$} & \multirow{2}{*}{$\begin{array}{c}\text { lower } \\
\text { section }\end{array}$} & \multicolumn{2}{|c|}{\begin{tabular}{|l} 
Galleria \\
\end{tabular}} & & & \multirow{2}{*}{\begin{tabular}{|c|} 
upper \\
section
\end{tabular}} & \multirow{2}{*}{$\begin{array}{c}\text { lower } \\
\text { section }\end{array}$} & \multicolumn{2}{|c|}{\begin{tabular}{|l|} 
Galleria \\
\end{tabular}} & & \\
\hline & & & Adult & IJs & & & & & Adult & IJs & & & & & Adult & IJs & & \\
\hline 1. & 201 & 1 & 0 & 0 & 202 & 40 & 301 & 12 & 2 & 7 & 313 & 63 & 285 & 22 & 8 & 9 & 307 & 61 \\
\hline 2. & 237 & 8 & 0 & 0 & 245 & 49 & 204 & 37 & 3 & 11 & 241 & 48 & 224 & 29 & 6 & 3 & 253 & 51 \\
\hline 3. & 192 & 6 & 0 & 0 & 198 & 40 & 251 & 14 & 1 & 5 & 265 & 53 & 297 & 34 & 2 & 16 & 331 & 66 \\
\hline 4. & 212 & 4 & 0 & 0 & 216 & 43 & 289 & 27 & 1 & 9 & 316 & 63 & 249 & 27 & 12 & 0 & 276 & 55 \\
\hline 5. & 226 & 7 & 0 & 0 & 233 & 47 & 267 & 31 & 2 & 8 & 298 & 60 & 324 & 31 & 4 & 31 & 355 & 71 \\
\hline 6. & 211 & 7 & 0 & 0 & 218 & 44 & 264 & 29 & 1 & 6 & 293 & 59 & 267 & 21 & 11 & 12 & 288 & 58 \\
\hline 7. & 224 & 5 & 0 & 0 & 229 & 46 & 295 & 19 & 4 & 8 & 314 & 63 & 241 & 13 & 17 & 23 & 254 & 51 \\
\hline 8. & 281 & 6 & 0 & 0 & 287 & 57 & 167 & 34 & 2 & 9 & 201 & 40 & 362 & 23 & 9 & 37 & 385 & 77 \\
\hline 9. & 267 & 4 & 0 & 0 & 271 & 54 & 246 & 18 & 1 & 3 & 264 & 53 & 219 & 34 & 14 & 26 & 253 & 51 \\
\hline 10. & 194 & 9 & 0 & 0 & 203 & 41 & 271 & 41 & 2 & 11 & 312 & 62 & 231 & 27 & 6 & 31 & 258 & 52 \\
\hline Mean & 225 & 6 & 0 & 0 & 230 & 46 & 256 & 26 & 2 & 8 & 282 & 56 & 270 & 26 & 9 & 19 & 296 & 59 \\
\hline \multicolumn{19}{|l|}{ Control } \\
\hline 1. & 179 & 70 & & & 249 & 50 & 306 & 49 & & & 355 & 71 & 336 & 30 & & & 366 & 73 \\
\hline 2. & 270 & 48 & & & 318 & 64 & 331 & 20 & & & 351 & 70 & 279 & 38 & & & 317 & 63 \\
\hline 3. & 238 & 52 & & & 290 & 58 & 262 & 21 & & & 283 & 57 & 261 & 47 & & & 308 & 62 \\
\hline 4. & 214 & 63 & & & 277 & 55 & 294 & 37 & & & 331 & 66 & 306 & 36 & & & 342 & 68 \\
\hline 5. & 231 & 57 & & & 288 & 58 & 318 & 28 & & & 346 & 69 & 289 & 41 & & & 330 & 66 \\
\hline 6. & 246 & 38 & & & 284 & 57 & 271 & 25 & & & 296 & 59 & 317 & 62 & & & 379 & 76 \\
\hline 7. & 268 & 46 & & & 314 & 63 & 319 & 58 & & & 377 & 75 & 297 & 49 & & & 346 & 69 \\
\hline 8. & 205 & 67 & & & 272 & 54 & 247 & 24 & & & 271 & 54 & 218 & 38 & & & 256 & 51 \\
\hline 9. & 198 & 49 & & & 247 & 49 & 269 & 29 & & & 298 & 60 & 342 & 24 & & & 366 & 73 \\
\hline 10. & 301 & 34 & & & 335 & 67 & 302 & 38 & & & 340 & 68 & 338 & 43 & & & 381 & 76 \\
\hline Mean & 235 & 52 & & & 287 & 57 & 292 & 33 & & & 325 & 65 & 298 & 41 & & & 339 & 68 \\
\hline
\end{tabular}

\section{$\mathrm{OH} 25$}

At 12 hrs, an average of 299 IJs were recovered out of 500 (the extraction efficiency was 60\%), whereas at 24 hrs, an average of 318 IJs (64\%) and, at $36 \mathrm{hrs}$, an average of 243 IJs (49\%) were recovered out of 500 . At $12 \mathrm{hrs}$, an average of $89.97 \%$ of the IJs were recovered in the upper section and only $10.03 \%$ in the lower section, whereas at 24 hrs, $91.5 \%$ were recovered in the upper and $8.5 \%$ in the lower and, at $36 \mathrm{hrs}, 91.4 \%$ in the upper and only $8.6 \%$ in the lower section on the average (Table 3).

\section{MEGIDIS}

At 12 hrs, an average of 282 IJs were recovered out of 500 (the extraction efficiency was 56\%), whereas at 24 hrs, an average of 283 IJs (57\%) and, at 36 hrs, an average of 256 IJs (51\%) were recovered out of 500 . The number of IJs recovered in the lower section increased as time went by. At 12 hrs, an average of $98.6 \%$ of the IJs were recovered in the upper section, and only $1.4 \%$ in the lower section, whereas at $24 \mathrm{hrs}, 97.2 \%$ were recovered in the upper and $2.8 \%$ in the lower and, at $36 \mathrm{hrs}, 91.8 \%$ in the upper and only $8.2 \%$ in the lower section on the average (Table 4). 
Table 3

Infective juveniles of Heterorhabditis bacteriophora (OH 25) detected in the lower and upper sections of the vials and in the Galleria larvae 12, 24 and 36 after injection

\begin{tabular}{|c|c|c|c|c|c|c|c|c|c|c|c|c|c|c|c|c|c|c|}
\hline \multirow{4}{*}{$\begin{array}{c}\text { Serial } \\
\text { number } \\
\text { of } \\
\text { replicates }\end{array}$} & \multicolumn{6}{|c|}{12 hrs } & \multicolumn{6}{|c|}{24 hrs } & \multicolumn{6}{|c|}{36 hrs } \\
\hline & \multicolumn{4}{|c|}{ Number of IJs in } & \multirow{3}{*}{$\begin{array}{c}\text { Total } \\
\text { nema } \\
\text { tode }\end{array}$} & \multirow{3}{*}{$\%$} & \multicolumn{4}{|c|}{ Number of IJs in } & \multirow{3}{*}{$\begin{array}{c}\text { Total } \\
\text { nema } \\
\text { tode }\end{array}$} & \multirow{3}{*}{$\%$} & \multicolumn{4}{|c|}{ Number of IJs in } & \multirow{3}{*}{$\begin{array}{c}\text { Total } \\
\text { nema } \\
\text { tode } \\
\end{array}$} & \multirow{3}{*}{$\%$} \\
\hline & \multirow{2}{*}{\begin{tabular}{|c|} 
upper \\
section
\end{tabular}} & \multirow{2}{*}{$\begin{array}{c}\text { lower } \\
\text { section }\end{array}$} & \multicolumn{2}{|c|}{ Galleria } & & & \multirow{2}{*}{\begin{tabular}{|c|} 
upper \\
section \\
\end{tabular}} & \multirow{2}{*}{$\begin{array}{c}\text { lower } \\
\text { section }\end{array}$} & \multicolumn{2}{|c|}{ Galleria } & & & \multirow{2}{*}{$\begin{array}{c}\text { upper } \\
\text { section }\end{array}$} & \multirow{2}{*}{$\begin{array}{c}\text { lower } \\
\text { section }\end{array}$} & \multicolumn{2}{|c|}{ Galleria } & & \\
\hline & & & Adult & IJs & & & & & Adult & IJs & & & & & Adult & IJs & & \\
\hline 1. & 263 & 22 & 0 & 0 & 285 & 57 & 304 & 33 & 6 & 0 & 337 & 67 & 213 & 11 & 2 & 0 & 224 & 45 \\
\hline 2. & 287 & 17 & 0 & 0 & 304 & 61 & 318 & 14 & 1 & 0 & 332 & 66 & 273 & 14 & 5 & 3 & 287 & 57 \\
\hline 3. & 263 & 54 & 0 & 0 & 317 & 63 & 301 & 24 & 3 & 1 & 325 & 65 & 278 & 24 & 3 & 1 & 302 & 60 \\
\hline 4. & 248 & 31 & 0 & 0 & 279 & 56 & 273 & 38 & 2 & 0 & 311 & 62 & 189 & 16 & 6 & 4 & 205 & 41 \\
\hline 5. & 301 & 28 & 0 & 0 & 329 & 66 & 288 & 22 & 4 & 1 & 310 & 62 & 176 & 22 & 8 & 2 & 198 & 40 \\
\hline 6. & 267 & 29 & 0 & 0 & 296 & 59 & 287 & 31 & 2 & 1 & 318 & 64 & 241 & 26 & 5 & 5 & 267 & 53 \\
\hline 7. & 254 & 18 & 0 & 0 & 272 & 54 & 266 & 26 & 4 & 0 & 292 & 58 & 198 & 23 & 6 & 1 & 221 & 44 \\
\hline 8. & 238 & 22 & 0 & 0 & 260 & 52 & 311 & 19 & 6 & 1 & 330 & 66 & 212 & 19 & 3 & 2 & 231 & 46 \\
\hline 9. & 269 & 51 & 0 & 0 & 320 & 64 & 291 & 27 & 4 & 1 & 318 & 64 & 226 & 29 & 8 & 3 & 255 & 51 \\
\hline 10. & 304 & 24 & 0 & 0 & 328 & 66 & 274 & 32 & 4 & 0 & 306 & 61 & 211 & 24 & 7 & 4 & 235 & 47 \\
\hline Mean & 269 & 30 & 0 & 0 & 299 & 60 & 291 & 27 & 4 & 1 & 318 & 64 & 222 & 21 & 5 & 3 & 243 & 49 \\
\hline \multicolumn{19}{|l|}{ Control } \\
\hline 1. & 254 & 28 & & & 282 & 56 & 267 & 42 & & & 309 & 62 & 279 & 17 & & & 296 & 59 \\
\hline 2. & 242 & 18 & & & 260 & 52 & 310 & 51 & & & 361 & 72 & 178 & 25 & & & 203 & 41 \\
\hline 3. & 275 & 39 & & & 314 & 63 & 301 & 47 & & & 348 & 70 & 133 & 33 & & & 166 & 33 \\
\hline 4. & 231 & 31 & & & 262 & 52 & 237 & 36 & & & 273 & 55 & 204 & 42 & & & 246 & 49 \\
\hline 5. & 261 & 29 & & & 290 & 58 & 212 & 32 & & & 244 & 49 & 238 & 36 & & & 274 & 55 \\
\hline 6. & 229 & 28 & & & 257 & 51 & 204 & 45 & & & 249 & 50 & 199 & 21 & & & 220 & 44 \\
\hline 7. & 242 & 12 & & & 254 & 51 & 261 & 51 & & & 312 & 62 & 208 & 34 & & & 242 & 48 \\
\hline 8. & 263 & 36 & & & 299 & 60 & 224 & 66 & & & 290 & 58 & 234 & 61 & & & 295 & 59 \\
\hline 9. & 241 & 26 & & & 267 & 53 & 249 & 38 & & & 287 & 57 & 221 & 44 & & & 265 & 53 \\
\hline 10. & 255 & 21 & & & 276 & 55 & 286 & 59 & & & 345 & 69 & 243 & 36 & & & 279 & 56 \\
\hline Mean & 249 & 27 & & & 276 & 55 & 255 & 47 & & & 302 & 60 & 214 & 35 & & & 249 & 50 \\
\hline
\end{tabular}

Table 4

Infective juveniles of Heterorhabditis megidis detected in the lower and upper sections of the vials and in the Galleria larvae 12, 24 and 36 after injection

\begin{tabular}{|c|c|c|c|c|c|c|c|c|c|c|c|c|c|c|c|c|c|c|}
\hline \multirow{4}{*}{$\begin{array}{c}\text { Serial } \\
\text { number } \\
\text { of } \\
\text { replicates }\end{array}$} & \multicolumn{6}{|c|}{12 hrs } & \multicolumn{6}{|c|}{24 hrs } & \multicolumn{6}{|c|}{36 hrs } \\
\hline & \multicolumn{4}{|c|}{ Number of IJs in } & \multirow{3}{*}{$\begin{array}{c}\text { Total } \\
\text { nema } \\
\text { tode }\end{array}$} & \multirow{3}{*}{$\%$} & \multicolumn{4}{|c|}{ Number of IJs in } & \multirow{3}{*}{$\begin{array}{c}\text { Total } \\
\text { nema } \\
\text { tode }\end{array}$} & \multirow{3}{*}{$\%$} & \multicolumn{4}{|c|}{ Number of IJs in } & \multirow{3}{*}{$\begin{array}{c}\text { Total } \\
\text { nema } \\
\text { tode } \\
\end{array}$} & \multirow{3}{*}{$\%$} \\
\hline & \multirow{2}{*}{$\begin{array}{c}\text { upper } \\
\text { section }\end{array}$} & \multirow{2}{*}{$\begin{array}{c}\text { lower } \\
\text { section } \\
\end{array}$} & \multicolumn{2}{|c|}{ Galleria } & & & \multirow{2}{*}{$\begin{array}{c}\text { upper } \\
\text { section }\end{array}$} & \multirow{2}{*}{$\begin{array}{c}\text { lower } \\
\text { section } \\
\end{array}$} & \multicolumn{2}{|c|}{ Galleria } & & & \multirow{2}{*}{$\begin{array}{c}\text { upper } \\
\text { section }\end{array}$} & \multirow{2}{*}{\begin{tabular}{|c|} 
lower \\
section
\end{tabular}} & \multicolumn{2}{|c|}{ Galleria } & & \\
\hline & & & Adult & IJs & & & & & Adult & IJs & & & & & Adult & IJs & & \\
\hline 1. & 261 & 5 & 0 & 0 & 266 & 53 & 253 & 6 & 0 & 0 & 259 & 52 & 217 & 13 & 0 & 0 & 230 & 46 \\
\hline 2. & 299 & 1 & 0 & 0 & 300 & 60 & 291 & 2 & 0 & 0 & 293 & 59 & 228 & 21 & 0 & 0 & 249 & 50 \\
\hline 3. & 257 & 3 & 0 & 0 & 260 & 52 & 287 & 7 & 0 & 0 & 294 & 59 & 236 & 14 & 0 & 0 & 250 & 50 \\
\hline 4. & 289 & 4 & 0 & 0 & 293 & 59 & 301 & 5 & 0 & 0 & 306 & 61 & 267 & 19 & 0 & 0 & 286 & 57 \\
\hline 5. & 316 & 2 & 0 & 0 & 318 & 64 & 238 & 8 & 0 & 0 & 246 & 49 & 194 & 23 & 0 & 0 & 217 & 43 \\
\hline 6. & 242 & 6 & 0 & 0 & 248 & 50 & 259 & 9 & 0 & 0 & 268 & 54 & 232 & 21 & 0 & 0 & 253 & 51 \\
\hline 7. & 268 & 2 & 0 & 0 & 270 & 54 & 267 & 11 & 0 & 0 & 278 & 56 & 217 & 16 & 0 & 0 & 233 & 47 \\
\hline 8. & 284 & 3 & 0 & 0 & 287 & 57 & 274 & 14 & 0 & 0 & 288 & 58 & 268 & 24 & 0 & 0 & 292 & 58 \\
\hline 9. & 277 & 4 & 0 & 0 & 281 & 56 & 288 & 6 & 0 & 0 & 294 & 59 & 253 & 27 & 0 & 0 & 280 & 56 \\
\hline 10. & 291 & 8 & 0 & 0 & 299 & 60 & 296 & 8 & 0 & 0 & 304 & 61 & 236 & 31 & 0 & 0 & 267 & 53 \\
\hline Mean & 278 & 4 & 0 & 0 & 282 & 56 & 275 & 8 & 0 & 0 & 283 & 57 & 235 & 21 & 0 & 0 & 256 & 51 \\
\hline \multicolumn{19}{|l|}{ Control } \\
\hline 1. & 228 & 2 & & & 230 & 46 & 230 & 15 & & & 245 & 49 & 205 & 22 & & & 227 & 45 \\
\hline 2. & 249 & 1 & & & 250 & 50 & 249 & 11 & & & 260 & 52 & 248 & 17 & & & 265 & 53 \\
\hline 3. & 231 & 5 & & & 236 & 47 & 231 & 14 & & & 245 & 49 & 231 & 15 & & & 246 & 49 \\
\hline 4. & 258 & 4 & & & 262 & 52 & 213 & 13 & & & 226 & 45 & 207 & 19 & & & 226 & 45 \\
\hline 5. & 261 & 6 & & & 267 & 53 & 279 & 11 & & & 290 & 58 & 269 & 24 & & & 293 & 59 \\
\hline 6. & 212 & 2 & & & 214 & 43 & 224 & 21 & & & 245 & 49 & 231 & 27 & & & 258 & 52 \\
\hline 7. & 226 & 3 & & & 229 & 46 & 257 & 11 & & & 268 & 54 & 219 & 24 & & & 243 & 49 \\
\hline 8. & 238 & 4 & & & 242 & 48 & 224 & 16 & & & 240 & 48 & 227 & 19 & & & 246 & 49 \\
\hline 9. & 243 & 1 & & & 244 & 49 & 243 & 12 & & & 255 & 51 & 216 & 18 & & & 234 & 47 \\
\hline 10. & 252 & 2 & & & 254 & 51 & 261 & 19 & & & 280 & 56 & 198 & 26 & & & 224 & 45 \\
\hline Mean & 240 & 3 & & & 243 & 49 & 241 & 14 & & & 255 & 51 & 225 & 21 & & & 246 & 49 \\
\hline
\end{tabular}


Figure 1: The percentage of infective juveniles of Heterorhabditis bacteriophora strains MHG3, KMD 19, OH 25, and a single strain of Heterorhabditis megidis recovered in the lower section of the vials at 12, 24 and $36 \mathrm{hrs}$ after injection

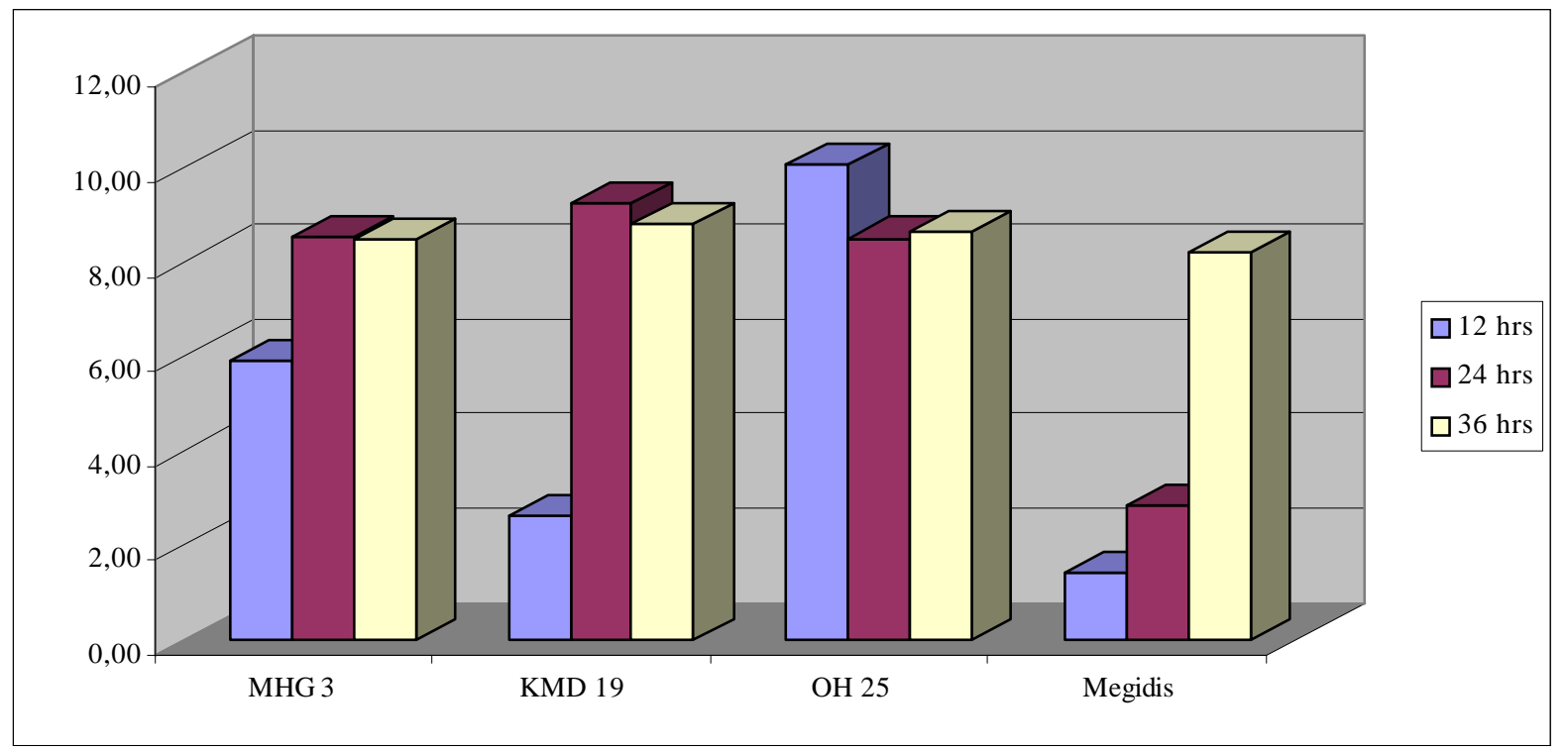

Figure 2: Adult and infective juveniles of Heterorhabditis bacteriophora strains MHG3, KMD 19, OH 25, and a single strain of Heterorhabditis megidis found in Galleria larvae dissected 72 hrs after an experiment that was conducted for 12, 24 and 36 hrs

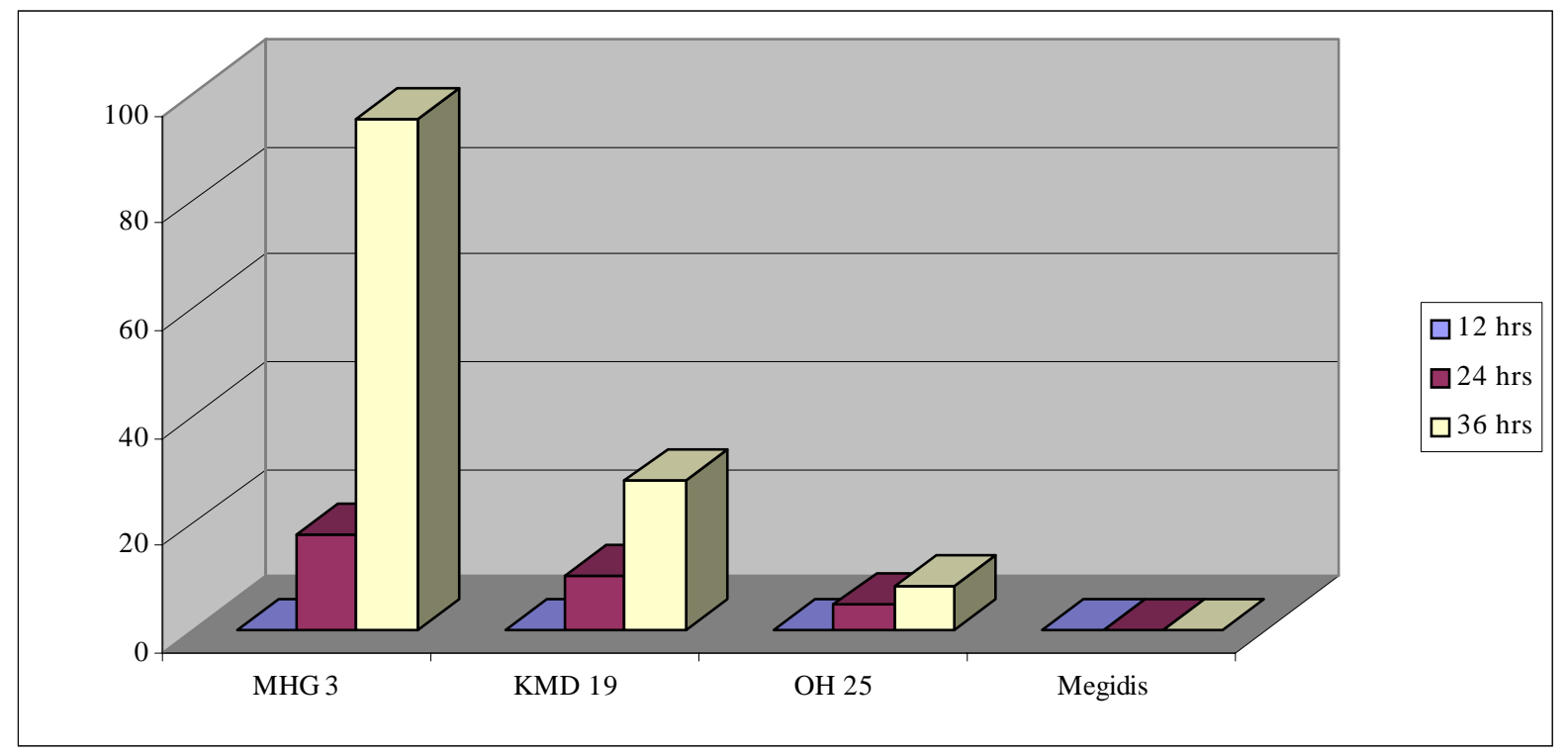

\section{DISCUSSION}

The number of the IJs in the upper section decreased in case of every isolate as time went by, except KMD 19. The most of IJs in the upper section could be found in the isolate Megidis, since 12 hrs after injection, an average of 278 IJs were recovered out of 500 (extraction efficiency: 55.6\%). The least number of IJs could be found in the upper section of the vials 12 hrs after injection in the case of the isolate $\mathrm{OH} 25$ (only an average of 269 IJs were recovered out of 500). As time went by, the IJs started their downward migration toward the Galleria larvae, therefore, their number decreased in the upper section of the shell vials and increased in the lower section of the vials (Figure 1). Only the isolate $\mathrm{OH}$ 25 behaved differently, because the number of IJs decreased in the case of these isolates in the lower section. This isolate was the quickest since, after 12 hrs, most IJs could be found in the lower section of the vials (an average of 30). The least IJs could be found in the case of Megidis (an average of 4). The number of IJs was so small in the lower section that 12 hrs after injection, only the isolates MHG 3 and $\mathrm{OH} 25$ could kill the Galleria larvae.

Besides the fact that mortality occurred among the Galleria larvae with the above isolates, neither IJs nor adults could be detected in neither living nor dead Galleria larvae 12 hrs after IJs injection. The number of IJs increased in every isolate in the lower section of the shell vials as time went by. The least IJs could be found in the lower section after $36 \mathrm{hrs}$ in case of the isolate MHG 3: only an average of 19 IJs could be detected. 
It is noteworthy that the behavior of the isolate Megidis was different from the other isolates: the number of the IJs was so negligible in the lower section of the vials that even after $36 \mathrm{hrs}$, none of the Galleria died and consequently neither adults nor IJs could be detected after dissecting the Galleria larvae.

According to the results of the present study we can conclude that the quickest nematode was the isolate $\mathrm{OH} \mathrm{25,} \mathrm{whereas} \mathrm{the} \mathrm{slowest} \mathrm{was} \mathrm{the} \mathrm{isolate}$ Megidis. The most IJs could be detected in the lower section of the vials in the case of $\mathrm{OH} 25$, and the least in the case of Megidis and KMD 19. Each isolate could reach the lower section of the vials, yet only the isolate Megidis could not infect and kill the host. After dissecting the larvae most IJs could be found in case of the isolate MHG 3 (95 IJs and adults) $36 \mathrm{hrs}$ after injection (Figure 2).

\section{ACKNOWLEDGEMENTS}

The authors thank Tünde Bacsó, Leslie Morris and Kate Peterson Taylor for helping in counting nematodes.

\section{REFERENCES}

Campbell, J. F.-Gaugler, R. (1993): Nictation behavior and its ecological implications in host search strategies of entomopathogenic nematodes. Behaviour 126. 155-169.

Gaugler, R.-LeBeck, L.-Nakagaki, B.-Boush, G. M. (1980) Orientation of the entomogenous nematode, Neoaplectana carpocapsae, to carbon dioxide, Environmental Entomology 8. 658.

Georgis, R.-Poinar, G. O. Jr. (1983): Effect of soil texture on the distribution and infectivity of Neoaplectana glaseri (nematoda: Steinernematidae). Journal of Nematology 15. 329-332.

Glazer, I.-Gaugler, R.-Segal, D. (1991): Genetics of the nematode Heterorhabditis bacteriophora Strain HP88: The diversity of beneficial traits. Journal of Nematology 23. 3. 324-333.

Grewal, P. S.-Lewis, E. E.-Gaugler, R.-Campbell, J. F. (1994): Host finding behaviour as a predictor of foraging strategy in entomopathogenic nematodes. Parasitology 108. 207-215.

Kaya, H. K.-Gaugler, R. (1993): Entomopathogenic nematodes. Annual Review of Entomology 38. 181-206.
Lewis, E. E.-Gaugler, R.-Harrison, R. (1992): Entomopathogenic nematode host finding: response to host contact cues by cruise and ambush foragers. Parasitology 105. 103-107.

Molyneux, A. S. (1983): The biology and ecology of entomopathogenic nematodes. Ph.D. Thesis, University of Tasmania. 189.

Molyneux, A. S.-Bedding, R. A. (1984): Influence of soil texture and moisture on the infectivity of Heterorhabditis sp. D1 and Steinernema glaseri for larvae of the sheep blowfly, Lucilia c. Nematologica 30. 3. 358-365.

Steiner, W. A. (1996): Dispersal and host-finding ability of entomopathogenic nematodes at low temperatures. Nematologica 42. 243-261.

White, G. F. (1924): A method for obtaining infective nematode larvae from cultures. Science 66. 302-303. 